\title{
Identity and Belonging in Leïla Slimani's Lullaby
}

\section{Onur Iş1k}

\section{Tokat Gaziosmanpasa University, Turkey / Contact: onur.isik@ gop.edu.tr}

\section{Abstract}

Goncourt Prize (2016) awarded Lullaby, a novel based on a real event, by Slimani tells a tragic story that ends with the killing of two children. Although the work seems like a thriller novel at a first glance, it exhibits a reflection of belonging and identity crisis in France. This crisis, for sure, is a result of France's long history of colonialism. Two protagonists of the novel, Myriam, the mother, and Louise, the nanny, are the ones who are unsatisfied with their identities and in need of belonging. This article aims to investigate the traces of colonialism's effect upon Slimani's characters, especially Myriam and Louise.

C 2021 The Literacy Trek \& the Authors - Published by The Literacy Trek APA Citation
Keywords

Belonging; Identity;

Lullaby; Race;

Slimani

Submission date

13.09.2022

Acceptance date

22.11.2021

Işık, O. (2021). Identity and belonging in Leïla Slimani’s Lullaby. The Literacy Trek, 7(2), 105-114. https://doi.org/10.47216/literacytrek.995047

\section{Introduction}

Leïla Slimani's 2016 novel Lullaby is known for sensational core. Goncourt Prize (2016) awarded novel of Slimani tells a tragic story that ends with the murder of two children. Masse family is at the center of the novel and the novel brings different subjects up for discussions such as racism, post-colonialism, and power relations in the society. The politics of the post-colonial era of France is at the heart of the novel as Massê family is an example of the conclusion of European efforts in the role of an exploiter/colonizer. That is why Madison Davis defines Lullaby as not only horror but also political fiction (2018, p.11).

The mother of the children, Myriam, is an Afro-French and she is a graduate of law school, however, she cannot perform her profession because of her burden of looking after her new-born baby boy and toddler girl. As she is not happy with her condition, Myriam decides to find a nanny, and together with Paul, her husband, they interview many possible nannies. Just one of the candidates makes them feel that they find the right person, who is Louise, a very experienced and lovely middle-aged white 
woman. In the first half of the novel, Massé family and Louise's relationship gradually starts to get closer. Nevertheless, it is seen that this intimacy ends up with despair and disappointment for both sides. In the end, Louise brutally kills Massé children and commits suicide.

The grotesque image of Louise is important to grasp the novel's nature. Louise's absurd appearance can be seen as a hint to of "half acquiescent, half oppositional, always untrustworthy" (Bhabha, 1994, p.33) nature. She tries to seem as decent as possible. To achieve that, she wears a uniform, treats children perfectly, and makes the flat as tidy as possible. The ridiculous dress makes her a comical figure for the people around her. Moreover, she is not interested in the safety of her daughter who has been lost for years. On the contrary, Louise seems very happy about being busy with Massé children. Although she is concerned with the children and their wellbeing, as the story unfolds it is seen that Louise wants to be not only a babysitter but also an inseparable member of the family. In the beginning, Louise succeeds to show herself as a part of the house. She takes care of everything including cooking for Paul and Myriam: "In a few weeks, Louise's presence has become indispensable" (2018, p. 23). The desire to become a part of a family and the family's resistance against this are outputs of class conflict. Myriam and Paul are representatives of the upper-middle class and Louise does not belong to this class. Myriam gives way to "an implacable enmity between native and invader" (Parry, 1987, p. 32) by hiring a babysitter. As a caregiver, Louise is neither a mother nor an authority in the household. This power clash can be classified as an identity crisis. Although Louise's identity secures her place in the society from the point of race, her position is problematic as she belongs to blue collars.

The entrance of Louise into the lives of the Massé family begins with Myriam's will to be back to work. This situation and family type are analyzed by Joan C. Tronto in The "Nanny" Question in Feminism. Although this article does not aim to address the issue with the feminist approach, it is still useful to discover the background of this class conflict:

"The two-career household is different even from dual-earner households in that both professionals in such a household hold down professional jobs where the time demands are excessive or unpredictable. The two-career households, and others similarly situated, are more likely to use a paid full-time domestic caretaker who either lives in the household or does not." (Tronto, 2002, p. 35) 
As is mentioned above, the two-career household has some specific differences from dual-earner households such as the work's demand of time and effort from the workers. More on that, it is possible to assume that the promotable status of a two-career household does not let the workers have private time and sphere. In this sense, the Massé family can be defined as one of those two-career households. If kindergarten is not a choice, these families are obliged to find a caretaker who, inevitably, belongs to a lower class, for their children. According to Kate Nelischer, Slimani's narrative demonstrates the Russian nesting dolls. As women get wealthier, they pass the responsibility of taking care of the child to a poorer woman (2018, para. 6). The class difference occurs since the prestige of being a nanny are not satisfying. On the other side, the mother and father of the children have jobs that push them for their future career. Myriam feels that finding a nanny is an urgency because from the eyes of her, being a stay-at-home mother is a disgraceful thing: "More than anything she feared strangers. The ones who innocently asked what she did for a living and who looked away when she said she was a stay-at-home mother" (2018, p.8).

Although Myriam has a dilemma over letting someone else take care of her children and going back to work again, she sees this as a challenge against the world and herself. Hence, according to her, hiring a babysitter becomes a bridge too far. Myriam's weakness against Louise emerges from here because Louise seems queerly perfect which amazes Myriam. Louise has a mistake-free history of childcare although she fails in taking care of her own child. As if that were not enough, Louise does the housework and takes the children out to play. That is more than Myriam could expect which becomes her vulnerable point.

The perfect image of Louise enables her to enter the family circle but that does not seem satisfying for her. The density of Louise's disappointment shows itself in the brutality of the killings of the children. It is not undeniable that Louise's brutality is a result of her identity and "identity only becomes an issue when it is in crisis, when something assumed to be fixed, coherent and stable is displaced by the experience of doubt and uncertainty" (Mercer, 1995, p. 43)

The disappointment and of course the brutality she carries within throughout her work in Massé house, are possible results of the national identity crisis. 
Zabunoğlu states "National identity, along with other identities, is important according to the meaning it offers to the life of the individual" (2018, p. 552). However, because of the class she belongs to, Louise cannot benefit from her national identity, which is white, and born to French parents. France, as known, is a multicultural state and it identifies itself as a nation-state to date. This unique style of identification is defined as follows:

\footnotetext{
"Unlike the United States, France has not distinguished between nationality (membership in a social community) and citizenship (a status entitling the holder to the rights and duties conferred by the state). But like the United States, the France of the revolution stressed the holding of appropriate political values- republicanism-as the essential criterion of membership in the national community." (Safran, 1991, p. 222)
}

Nevertheless, with the power of globalization and technology, it is impossible to reject the idea of a "global village". The development of technological opportunities has made people understand each other better than past. This situation has also led disappearance of minor cultures. The effort of communication gives way to the creation of global cultures instead of separate cultures for each state. Most probably, as a result of this process, humankind will have only one culture, meaning extinction of nation-states as Khan suggests: "In view of unfolding global realities, the concept of territorial sovereignty seems awkward and anachronistic; it is frequently incompatible with new aspirations of the peoples of the world" (2007, p. 201). As a result of the ideas stated above, it is possible to assume that contemporary states are in a needless effort of keeping the nation-state principle. France is just one of these examples. In Lullaby, Slimani foregrounds the incompatibility of the situation over Louise. From the lenses of the thought which categorizes citizenship according to race, descendants, and culture fails. Although French nationalism suggests a definition over common ideal, it is a known fact that this thought is not in effect. The disharmony in Lullaby confirms this reality. The disharmony emerges from the unusual confrontation between middle-class Afro-French employers and poor white babysitters. Even though this is not directly mentioned in the novel, it requires a simple but interlinear reading that Louise thinks that she is the one who deserves to be in the place of Myriam.

Louise's family life is also important in terms of understanding the motivation behind the massacre of children. Her husband, Jacques does not love her, and Louise hates and ignores her daughter without a rational reason. It is for sure that 
disappointment follows anger for her. In exchange for failure of her dreams, Louise sacrifices Massê children. The slaughter scene at the end of the novel is no doubt that associated with deep-seated racial problems.

According to Frantz Fanon, the west differentiates itself from the rest of the world so that it guarantees a totally different appearance it had in the past. Pulling out of a barbaric history is not, of course, an easy task. However, it is possible to claim that despite its role in the past, Europe has achieved to continue its progress.

"The West saw itself as a spiritual adventure. It is in the name of the spirit, in the name of the spirit of Europe, that Europe has made her encroachments, that she has justified her crimes and legitimized the slavery in which she holds four-fifths of humanity. Yes, the European spirit has strange roots." (1991, p. 373)

Myriam is a descendant of the African nation, and she seems so accustomed to the new approach of the West that she comes to a point where she denies her roots. In that, the process of selection of a nanny is no exception. Paul and Myriam have some criteria for the potential nanny:

\footnotetext{
"No illegal immigrants, agreed? For a cleaning lady or a decorator, it doesn't bother me. Those people have work, after all. But to look after the little ones, it's too dangerous. I don't want someone who'd be afraid to call the police or go to the hospital if there was a problem. Apart from that... not too old, no veils and no smokers. The important thing is that she's energetic and available. That she works so we can work.” $(2018$, p. 4)
}

From the quote above, it is clear that an Afro-French, Myriam, becomes a supporter of the racist tendencies, which were against her and her family in the past. As she overcame the difficulties of bearing the racial distinction, she thinks that she could be one of "them". This situation is also a confirmation of alienation. Fanon explains this as "alienation is the result of a fear of the Negro, a fear aggravated by determining circumstances" (1986, p. 209). Although immigrants and minorities see their future in a common place, that is, in the country where they live, the main distinction between these groups lies in where their past is. Even minorities have prejudices against immigrants, and they exhibit it as if it were a standard thing to do. Minorities' reaction to immigrants reveals the anxiety of being identified with these "second-class" people because minorities accept themselves as the justified citizens of the country. 
Moreover, minorities do not show mercy as follows: "“[...] If she has children, it'd be better if they're back in her homeland.' Myriam thanked her for the advice" (2018, p.4). According to Myriam's friend, the nanny should be apart from her children if she has children so that she will be focused on the children of the employer. A superior-subordinate relationship is also important to Myriam and Paul as it can be seen from here:

\footnotetext{
"They want the nannies to see that they are good people; serious, orderly people who try to give their children the best of everything. The nannies must understand that Myriam and Paul are the ones in charge here." (2018, p. 5)
}

In the quote above Myriam and Paul exhibit the role Europe plays. It is seen that this is an effort of making the possible nannies know that they have no equal rights with them in their territory. Slimani makes the European attitude towards immigrants resonate in the minds of Myriam and Paul.

Phobogenesis is a term used by Franz Fanon to explain the European fear and hatred emerging from the encounter with a black person. According to Fanon this is a common thing for the Europeans, and they do not recognize it consciously. It, certainly, causes a hypocritical approach towards black people. In his own words Fanon says: "The European knows and he does not know. On the level of reflection, a Negro is a Negro; but in the unconscious there is the firmly fixed image of the niggersavage" (1986, p. 199). From the quote, it can be assumed that the main problem, in that case, is that the Europeans are not aware of their perception of blacks which dates back to the imperial age. In connection with this, it is clear that Myriam is one of the members of the group defined by Fanon as being afraid of blacks:

"Myriam had been perfectly clear. She does not want to hire a North African to look after the
children. 'It'd be good,' people told her. 'Try to convince Paul. She could speak Arabic to
them since you don't want to.' But Myriam steadfastly refuses this idea. She fears that a tacit
complicity and familiarity would grow between her and the nanny. That the woman would
start speaking to her in Arabic. Telling Myriam her life story and, soon, asking her all sorts of
favours in the name of their shared language and religion. She has always been wary of what
she calls immigrant solidarity." (2018, p. 16)
Immigrant solidarity, in other words, the minority's only way of survival seems like a disgusting thing for Myriam. She does not feel any belonging to her race. Moreover, she spends an effort to avoid being together under the same roof with those people. From the quotation above it is not wrong to say that she puts a barrier between her true identity and her created, idealized middle-class French woman profile. It is indisputable to put forward the idea that like in the United States, being white, a 
member of the biggest religious group, and having the strongest race heritage in the country make the one away from being labeled as persona non grata in France. Here it is meant that each state has its privileged citizens, and France is not an exception. That is why Myriam's struggle against her past and race is not in vain. She tries to structure and preserve her identity following the unwritten law of France. Having an African nanny in the house is possibly a threat to this order. As it was mentioned before, the new-comers, immigrants are signifiers of a possible threat that the existence of immigrants might be used as an excuse to attack to minorities.

From the beginning till the end, the novel follows a linear pattern which consists of Louise's desire for possession. All her efforts of making herself one of the indispensable parts of the family indicate only one target: to satisfy her desire to possess. She presents a content profile in her temporal satisfaction moments as in the quotation below:

"She feels a serene contentment when - with Adam asleep and Mila at school - she can sit down and contemplate her task. The silent apartment is completely under her power, like an enemy begging for forgiveness." (2018, p. 24)

Louise's perception of the apartment above as an "enemy" is a crucial symbol to understand her attitude towards the family. The important point here is that Louise sees the apartment as a signifier of Massés. Intrinsically, according to Louise Massés are her enemy. Slimani's "stress on power is in conjunction with other forms of power which seek domination" (Özer-Taniyan, 2020, p. 94). Louise tries to dominate the family with explicit and implicit ways. Again, the subject of possession steps in here. As she sees the family as an enemy to her, she does not see any objection to intruding on their lives and occupying the spheres they own.

Belonging on the other hand, for Myriam, is an arbitrary thing. While she desires to be one of the highest-class members of society, she is also aware that the private sphere and life are priceless. This can be applied to her relationship with Louise. The existence of Louise at home, in the eyes of Myriam, is a kind of intruder. Although Myriam is conscious of their dependence on Louise, she is distressed by her transgression. This dependence, indispensability in other words, causes her to think that she is not free as below: 
"We will, all of us, only be happy, she thinks, when we don't need one another any more. When we can live a life of our own, a life that belongs to us, that has nothing to do with anyone else. When we are free.” (2018, p. 33)

Massés are so dependent on Louise that they know how much comfort she gives them, and this situation becomes a dead end. Paul informs Myriam about his thoughts about Louise:

\begin{abstract}
"He knows how much they need Louise, but he can't stand her any more. With her doll's body, her irritating habits, she really gets on his nerves. 'She's so perfect, so delicate, that sometimes it sickens me,' he admitted to Myriam one day. He is horrified by her little-girl figure, that way she has of dissecting every little thing the children do or say. He despises her dubious theories on education and her grandmotherly methods." (2018, p. 105)
\end{abstract}

Unbearable comfort offered them by Louise is an important factor in keeping her in the family. Louise's perfection is a kind of guard of her against all possible threats of being suspended from the family. Louise tries to keep this excellency until the moments of crisis such as Massés' plan of having a holiday without her: "How gloomy she looked, Louise, when Myriam told her that they were going to the mountains for a week to stay with Paul's parents!" (2018, p. 110). This is one of the first of the clashes Massés and Louise have. Although Louise does not say anything about her feelings after hearing the news about the plan, it can be inferred that she understands that her position in the family is not permanent, but temporary. This temporariness disturbs her as she realizes that she is not a member of the family. As a result of this awareness gives a way to a dramatic turnabout and the fiction reaches the peak as follows:

\footnotetext{
"Myriam is about to open the fridge when she sees it. There, in the middle of the little table where the children and their nanny eat. A chicken carcass sits on a plate. A glistening carcass, without the smallest scrap of flesh hanging from its bones, not the faintest trace of meat. It looks as if it's been gnawed clean by a vulture or a stubborn, meticulous insect. Some kind of repulsive animal, anyway." (2018, p. 145)
}

The leftover can be seen as an abject figure as it signifies death. Moreover, if the scene is taken into account from a different perception, it is a denouncement of the novel's end. In the light of this context, a gradual change in the attitudes of Louise towards the children is reflected upon the carcass of the chicken left on the table. This symbol on the table is so important that it is a kind of border that has already been transgressed by Louise. Louise's aim to be an indispensable part of the family is so strong that "she has only one desire: to create a world with them, to find her place and 
live there, to dig herself a niche, a burrow, a warm hiding place" (2018, p. 170). However, as time passes Louise thinks that a third child might be a solution to all her problems. Yet, the children "are an obstacle to the baby's arrival. It's the children's fault if their parents are never alone together" (2018, p. 183).

As a result of her reasoning, Louise finds the guilty ones and kills them in the bathroom. As it was said, she kills the children as a message to Massés to whom she has never said anything about her anxiety before.

In a brief conclusion, Lullaby stands as an unusual novel that is based on a real event with its harsh criticism of France's long history of colonialism and grotesque style. It has been exhibited that Lullaby's harshness comes from Louise's grotesque characterization. Louise's excellency at her service in the household and silence despite her distress, is broken when the time comes to understand her temporariness. She finds herself in a deadlock and to get revenge she uses the children as her victims. Her colonized position is presented as an excuse for her violent act. The novel consists of two polar sides which are silence and violence. These two should be taken as the symbols presented by Slimani as the summary of the colonial history of France. In connection with this, it is possible to assume that Myriam and Louise are representations of colonizer and colonized. Hence, in the times of post-colonialism a reversed recolonization process is exhibited. Although Louise symbolizes the colonizer of the past, she no longer has the power of domination. That is why she sees herself superior to Massés by calling them "enemy" (2018, p. 24). This might be seen as an effort of regaining the dominance. This clash is an exemplar of slave-master relationship. Hence, it justifies that after the abolition of official colonialism there has been no cultural change.

\section{Notes on the Contributor}

Onur Işık (Ph.D.) is currently working at Tokat Gaziosmanpaşa University as a lecturer in the department of Foreign Languages and Cultures. He researches on American literature, Gothic literature, comparative literature, and psychoanalytic criticism. 


\section{Endnotes}

${ }^{1}$ The Lullaby displays its intertextuality here. The theme of governess, which belongs to the Victorian tradition, is also evident in this novel. In the novels of Victorian period, the female character who comes to the house as a caregiver could not avoid being a part of the house. However, since the main theme of this article is not intertextuality, the subject is mentioned in this footnote.

\section{References}

Achille, E. (2019). Behind closed doors: Postcolonial domesticity, whiteness, and the making of petits Blancs. Revue critique de fixxion française contemporaine, 19, 147-155.

Bhabha, H. K. (1994). The location of culture. Routledge.

Davis, J. M. (2018). The nightmare tropes of three women writers: Leïla Slimani, Karen Dionne, and Yrsa Sigurðardóttir. World Literature Today, 92(4), 10-12.

Fanon, F. (1986). Black skin, white masks. Pluto Press.

Fanon, F. (1991). The wretched of the earth. Grove Weidenfeld.

Khan, L. A. (1996). The Extinction of Nation-States. Developments in International Law, 21.

Mercer, K. (1995). Welcome to the jungle: Identity and diversity in postmodern politics. In J. Rutherford (Ed.). Identity: Community, culture, difference, London (pp. 43-71). Lawrence \& Wishart.

Nelischer, K. (2018). Women's right to the city. The Site Magazine. Retrieved on September 11, 2021 from https://www.thesitemagazine.com/read/womensright-to-the-city

Parry, B. (1987). Problems in current theories of colonial discourse. Oxford Literary Review, 9(1), 27-58.

Safran, W. (1991). State, nation, national identity, and citizenship: France as a test case. International Political Science Review, 12(3), 219-238.

Slimani, L. (2018). Lullaby. Faber \& Faber.

Özer-Taniyan, R. (2020). Raja of Narayan: A colonised tiger or a nation?. The Literacy Trek, 6(2), 91- 103. https://doi.org/10.47216/literacytrek.700566

Tronto, J. C. (2002). The "nanny" question in feminism. Hypatia, 17(2), 34-51.

Zabunoğlu, H. G. (2018). Günümüzde ulus-devlet. Erciyes Üniversitesi Hukuk Fakültesi Dergisi, 13(1), 535-559. 